\title{
Airway response to salbutamol: effect of regular salbutamol inhalations in normal, atopic, and asthmatic subjects
}

\author{
JE HARVEY, AE TATTERSFIELD \\ From the Faculty of Medicine, Southampton General Hospital, Tremona Road, Southampton
}

ABSTRACT This study was designed to determine whether resistance to the airway effects of the beta-agonist, salbutamol, would develop in three groups of subjects while taking large doses of inhaled salbutamol. Six normal non-atopic, six atopic non-asthmatic, and eight atopic asthmatic subjects were studied by an identical technique. The development of resistance was assessed from salbutamol dose-response studies in which the airway response was measured as specific airway conductance (sGaw). Further evidence was sought in the atopic and asthmatic subjects by measuring the airway response to a standard histamine inhalation challenge and the protective effect of $100 \mu \mathrm{g}$ salbutamol on this challenge, and by six-hourly peak flow recordings. Subjects were assessed before and during four weeks in which they took inhaled salbutamol regularly in doses increasing to $500 \mu \mathrm{g}$ qid in week 4. Normal subjects showed a progressive reduction in the bronchodilator (sGaw) response to salbutamol during the four weeks, indicating the progressive development of resistance. The atopic subjects, both asthmatic and non-asthmatic, showed no reduction in the response to salbutamol during the four weeks, nor any change in the response to histamine challenge or in regular peak flow readings. These results demonstrate that asthmatic patients do not develop bronchial beta-adrenoceptor resistance easily and suggests that they and atopic non-asthmatic subjects are less susceptible to its development than normal subjects.

When the sales of isoprenaline aerosols were found to have increased and decreased in parallel with the rise and fall in asthma deaths in the United Kingdom in the 1960 s, a causative association was suggested ${ }^{1}$ and though supported by circumstantial evidence was never proved. ${ }^{2} 3$ Explanations for a possible association included the provocation of cardiac arrythmias by isoprenaline ${ }^{3}$ or alternatively the development of tolerance or resistance to this and other beta-agonists so that patients would then fail to respond to either endogenous or exogenous catecholamines during an acute episode of asthma. ${ }^{4}$ This possibility was supported by two retrospective studies of patients taking excessive amounts of inhaled isoprenaline who, when tested, showed little bronchodilator response to inhaled isoprenaline. Once isoprenaline inhaler usage was reduced or discontinued their bronchodilator response returned..$^{5}$ The development of beta-adrenoceptor

Address for reprint requests: Dr JE Harvey, St Martin's Hospital, Midford Road, Bath BA2 5RP. resistance after beta-agonist treatment has been demonstrated for the tremor, ${ }^{7}$ metabolic, ${ }^{8-10}$ heart rate, ${ }^{411}$ and white cell cyclic-AMP12 14 responses to beta-agonists in both normal subjects and patients with asthma. The important question of whether patients with asthma develop bronchial betaadrenoceptor resistance as a result of large or even moderate doses of beta-agonists has been investigated in more than $\mathbf{3 0}$ studies in the last decade. In the majority, drug-induced bronchial resistance could not be demonstrated, ${ }^{75-18}$ and when it did occur the changes were usually small.1019-21 This is in contrast to the only study in normal subjects where bronchial beta-adrenoceptor resistance developed progressively over four weeks as subjects took increasing doses of inhaled salbutamol. ${ }^{22}$ This apparent difference between normal and asthmatic subjects may be a true difference, or may be the result of differences in technique and problems inherent in studying patients with asthma.

This study was therefore designed to compare three groups of subjects using an identical technique 
Table 1 Details of subjects in the three groups

\begin{tabular}{llccc}
\hline & & Normal & Atopy & Asthma \\
\hline Sex & Male & 5 & 4 & 7 \\
& Female & 1 & 2 & 1 \\
Age (years) & Mean & 31 & 32 & 29 \\
& Range & $18-57$ & $23-50$ & $22-53$ \\
\% predicted & FEV & 117 & 113 & 91 \\
& SEM & 7.4 & 3.9 & 8.0 \\
\hline
\end{tabular}

-normal subjects, atopic non-asthmatic subjects, and atopic asthmatic patients. Subjects were studied before and during four weeks in which they inhaled increasing doses of salbutamol.

\section{Methods}

\section{SUB JECTS}

All subjects agreed to participate after a full explanation of the protocol which was agreed by the Southampton Ethical Committee. Details of the six normal subjects, six atopic non-asthmatic subjects, and eight asthmatic subjects who participated are shown in table 1; all were non-smokers.

Normal subjects were healthy, had no respiratory symptoms, and no personal or family history of asthma or allergy. All had negative skin prick tests to five common allergens and less than $10 \%$ change in $\mathrm{FEV}_{1}$ after $100 \mu \mathrm{g}$ inhaled salbutamol.

The atopic non-asthmatic subjects gave a typical history of hay fever and had at least two positive skin prick tests to five common allergens, one being mixed grass pollen. They showed less than $10 \%$ change in PEFR during recordings four times daily for four days and after $100 \mu \mathrm{g}$ inhaled salbutamol, and less than $10 \%$ fall in $\mathrm{FEV}_{1}$ after six minutes' exercise on a bicycle ergometer at 100 watts and after a two-minute inhalation of $0.5 \%$ histamine. They were studied in winter when asymptomatic.

The asthmatic subjects gave a history of intermittent wheezing attacks for at least five years, had positive skin prick tests to at least two of five common allergens, and a minimum $15 \%$ fluctuation in FEV 1 or PEFR spontaneously or after $100 \mu \mathrm{g}$ inhaled salbutamol. Their asthma had never necessitated hospital admission nor steroid therapy. All had recently been in good health requiring only an occasional inhalation of salbutamol (less than five in the preceding month). No other treatment was taken before or during the study by any subject.

\section{INHALED SALBUTAMOL DOSE-RESPONSE STUDIES}

Airway resistance was measured in a constant volume body plethysmograph and expressed as specific airway conductance (sGaw), the reciprocal of airway resistance divided by lung volume. For each measurement a set of 12 tracings was recorded on light sensitive paper. Each set was then coded and read blind by an independent observer to obtain a mean value for sGaw. ${ }^{23}$ Measurements were made 10 minutes after the subject inhaled increasing doses of salbutamol from specially prepared metered aerosols providing cumulative doses of salbutamol from 10 to $600 \mu \mathrm{g}$.

\section{HISTAMINE CHALLENGE STUDIES}

Pilot studies on each asthmatic and each atopic subject determined the concentration of histamine required to cause a fall in $\mathrm{FEV}_{1}$ of at least $20 \%$ and this concentration was used throughout the study. Histamine acid phosphate diluted in normal saline was inhaled from a Wright's nebuliser during tidal breathing, using compressed air at six litres/min. Measurements of sGaw were made before and immediately after a two-minute inhalation, and again after 30 minutes recovery. The subject then inhaled salbutamol $(100 \mu \mathrm{g})$, sGaw was measured 10 minutes later and finally repeated after a second histamine challenge.

Table 2 Mean baseline values for sGaw and FEV $\pm S E M$

\begin{tabular}{|c|c|c|c|c|c|c|c|}
\hline \multicolumn{2}{|c|}{ Salbutamol dose-response studies } & \multicolumn{2}{|c|}{ Normal } & \multicolumn{2}{|l|}{ Atopy } & \multicolumn{2}{|l|}{ Asthma } \\
\hline & & Mean & $S E M$ & Mean & $S E M$ & Mean & $S E M$ \\
\hline sGaw & Control & $1 \cdot 69$ & $0 \cdot 11$ & $1 \cdot 90$ & $0 \cdot 10$ & $1 \cdot 35 \triangle$ & $0 \cdot 13$ \\
\hline \multirow{2}{*}{ FEV $_{1}$} & $\begin{array}{l}\text { Week } 4 \\
\text { Control }\end{array}$ & $\begin{array}{l}1.90 \\
4 \cdot 62\end{array}$ & $\begin{array}{l}0.11 \\
0.30\end{array}$ & $\begin{array}{l}1 \cdot 84 \\
4 \cdot 45\end{array}$ & $\begin{array}{l}0.08 \\
0.32\end{array}$ & $\begin{array}{l}1 \cdot 30 \\
3 \cdot 68 \triangle\end{array}$ & $\begin{array}{l}0 \cdot 14 \\
0 \cdot 36\end{array}$ \\
\hline & Week 4 & $4 \cdot 62$ & $0 \cdot 28$ & $4 \cdot 21 *$ & $0 \cdot 30$ & $3 \cdot 33^{*}$ & $0 \cdot 37$ \\
\hline \multicolumn{8}{|c|}{ Histamine challenge studies } \\
\hline sGaw & Control & & & $1 \cdot 81$ & 0.11 & $1.46 \triangle$ & 0.14 \\
\hline \multirow{2}{*}{$\mathrm{FEV}_{1}$} & $\begin{array}{l}\text { Week } 4 \\
\text { Control }\end{array}$ & & & $\begin{array}{l}1 \cdot 76 \\
4 \cdot 38\end{array}$ & $\begin{array}{l}0.12 \\
0.36\end{array}$ & $\begin{array}{l}1.48 \\
3.69 \triangle\end{array}$ & $\begin{array}{l}0 \cdot 23 \\
0 \cdot 37\end{array}$ \\
\hline & Week 4 & & & $4 \cdot 29$ & $0 \cdot 36$ & $3 \cdot 60$ & $0 \cdot 35$ \\
\hline
\end{tabular}

$\triangle \mathrm{p}<0.05$ asthma versus normal and atopic subjects. ${ }^{*} \mathrm{p}<0.05$ week 4 versus control. $\mathrm{sGaw}$ is in $\mathrm{s}^{-1} \mathrm{kPa}^{-1}$ and $\mathrm{FEV}_{1}$ in litres. 
Table 3 Salbutamol dose-response studies-mean change in sGaw $\left(s^{-1} \mathrm{kPa}^{-1}\right)$ and $F E V_{1}$ before and after $600 \mu \mathrm{g}$ salbutamol

\begin{tabular}{|c|c|c|c|c|c|c|c|c|c|}
\hline \multirow{2}{*}{$\begin{array}{l}\text { Control } \\
\text { sGaw }\end{array}$} & \multicolumn{3}{|c|}{ Normal } & \multicolumn{3}{|l|}{ Atopy } & \multicolumn{3}{|c|}{ Asthma } \\
\hline & Mean & $S E M$ & $\%$ change & Mean & $S E M$ & $\%$ change & Mean & $S E M$ & $\%$ change \\
\hline $\begin{array}{l}\text { Control baseline } \\
600 \mu \mathrm{g} \\
\text { Week } 1 \text { baseline } \\
600 \mu \mathrm{g} \\
\text { Week } 2 \text { baseline } \\
600 \mu \mathrm{g} \\
\text { Week } 3 \text { baseline } \\
600 \mu \mathrm{g} \\
\text { Week } 4 \text { baseline } \\
600 \mu \mathrm{g}\end{array}$ & $\begin{array}{l}1 \cdot 69 \\
2 \cdot 71 \\
1 \cdot 86 \\
2 \cdot 72 \\
1 \cdot 81 \\
2 \cdot 56 \\
1 \cdot 82 \\
2 \cdot 48 \\
1 \cdot 90 \\
2 \cdot 40\end{array}$ & $\begin{array}{l}0 \cdot 11 \\
0 \cdot 09 \\
0 \cdot 14 \\
0 \cdot 07 \\
0 \cdot 12 \\
0 \cdot 13 \\
0 \cdot 14 \\
0 \cdot 12 \\
0 \cdot 11 \\
0 \cdot 10\end{array}$ & $\begin{array}{l}60 \\
46 \\
41 \\
36 \\
26\end{array}$ & $\begin{array}{l}1 \cdot 90 \\
2 \cdot 47 \\
1 \cdot 81 \\
2 \cdot 52 \\
1 \cdot 64 \\
2 \cdot 37 \\
- \\
- \\
1 \cdot 84 \\
2 \cdot 59\end{array}$ & $\begin{array}{l}0.10 \\
0 \cdot 13 \\
0.08 \\
0 \cdot 16 \\
0 \cdot 11 \\
0.24 \\
- \\
- \\
0.08 \\
0.32\end{array}$ & $\begin{array}{l}30 \\
39 \\
45 \\
- \\
41\end{array}$ & $\begin{array}{l}1 \cdot 35 \\
2 \cdot 23 \\
1 \cdot 32 \\
2 \cdot 37 \\
1 \cdot 51 \\
2 \cdot 56 \\
1 \cdot 45 \\
2 \cdot 26 \\
1 \cdot 30 \\
2 \cdot 51\end{array}$ & $\begin{array}{l}0 \cdot 13 \\
0 \cdot 21 \\
0 \cdot 17 \\
0 \cdot 31 \\
0 \cdot 25 \\
0 \cdot 28 \\
0 \cdot 15 \\
0 \cdot 20 \\
0 \cdot 14 \\
0 \cdot 25\end{array}$ & $\begin{array}{l}65 \\
80 \\
70 \\
56 \\
93\end{array}$ \\
\hline $\begin{array}{l}F E V_{1} \\
\text { Control baseline } \\
600 \mu \mathrm{g} \\
\text { Week } 4 \text { baseline } \\
600 \mu \mathrm{g}\end{array}$ & $\begin{array}{l}4 \cdot 62 \\
4 \cdot 88 \\
4 \cdot 62 \\
4 \cdot 90\end{array}$ & $\begin{array}{l}0.30 \\
0.29 \\
0.28 \\
0.28\end{array}$ & $\begin{array}{l}5 \\
6\end{array}$ & $\begin{array}{l}4 \cdot 45 \\
4 \cdot 57 \\
4 \cdot 21 \\
4 \cdot 47\end{array}$ & $\begin{array}{l}0.32 \\
0.33 \\
0.30 \\
0.34\end{array}$ & $\begin{array}{l}3 \\
6\end{array}$ & $\begin{array}{l}3 \cdot 68 \\
4 \cdot 02 \\
3 \cdot 33 \\
3 \cdot 86\end{array}$ & $\begin{array}{l}0.36 \\
0.39 \\
0.37 \\
0.32\end{array}$ & $\begin{array}{r}9 \\
16\end{array}$ \\
\hline
\end{tabular}

\section{PROTOCOL}

Three control inhaled salbutamol dose-response studies were carried out on each subject on separate days. The asthmatic and atopic, non-asthmatic subjects also carried out a separate control histamine challenge study, and made regular six-hourly PEFR recordings at home for four days. When control studies were complete, subjects were asked to inhale salbutamol for four weeks, $100 \mu \mathrm{g}$ four times a day for the first week, and increasing to 300,400 , and $500 \mu \mathrm{g}$ four times a day during weeks 2,3 , and 4 respectively. An inhaled salbutamol dose-response study was carried out at the end of each week, 12 hours after the last salbutamol inhalation. During week 4 the asthmatic and atopic subjects carried out a histamine challenge study and repeated the sixhourly PEFR recordings for four days.

\section{STATISTICAL ANALYSIS}

Salbutamol dose-response curves were constructed by plotting sGaw against the cumulative dose of inhaled salbutamol. The mean of three separate dose-response studies was used to obtain the control dose-response curve. Values of sGaw during the four weeks of treatment were compared for each dose of salbutamol by the Mann-Whitney $U$ test.

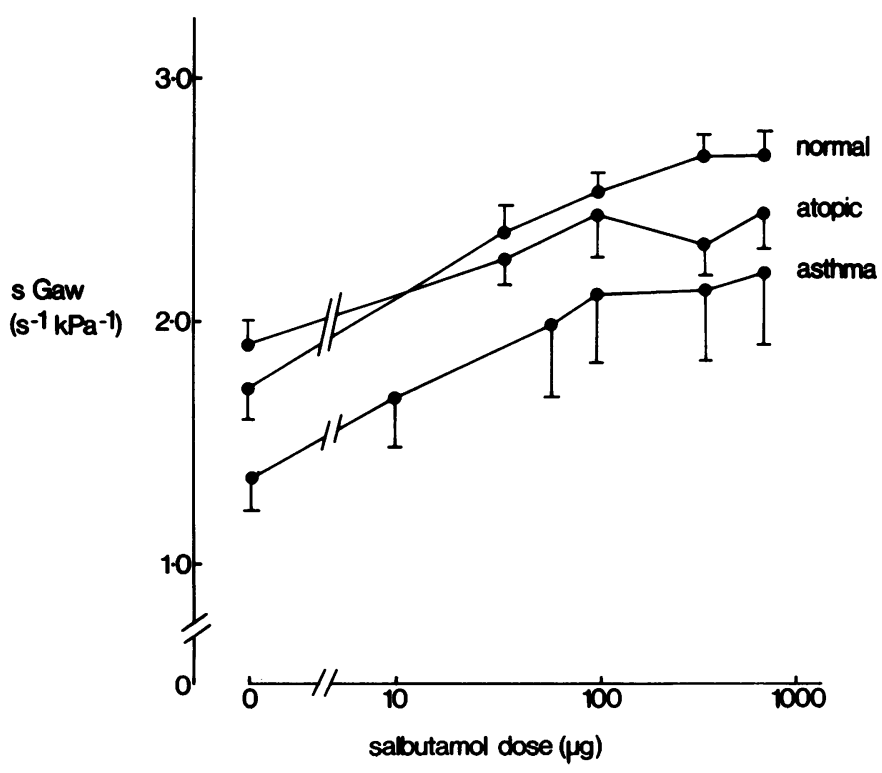

Fig 1 Mean sGaw values + SEM for three control dose-response studies for six normal, six atopic, non-asthmatic, and eight asthmatic subjects. 


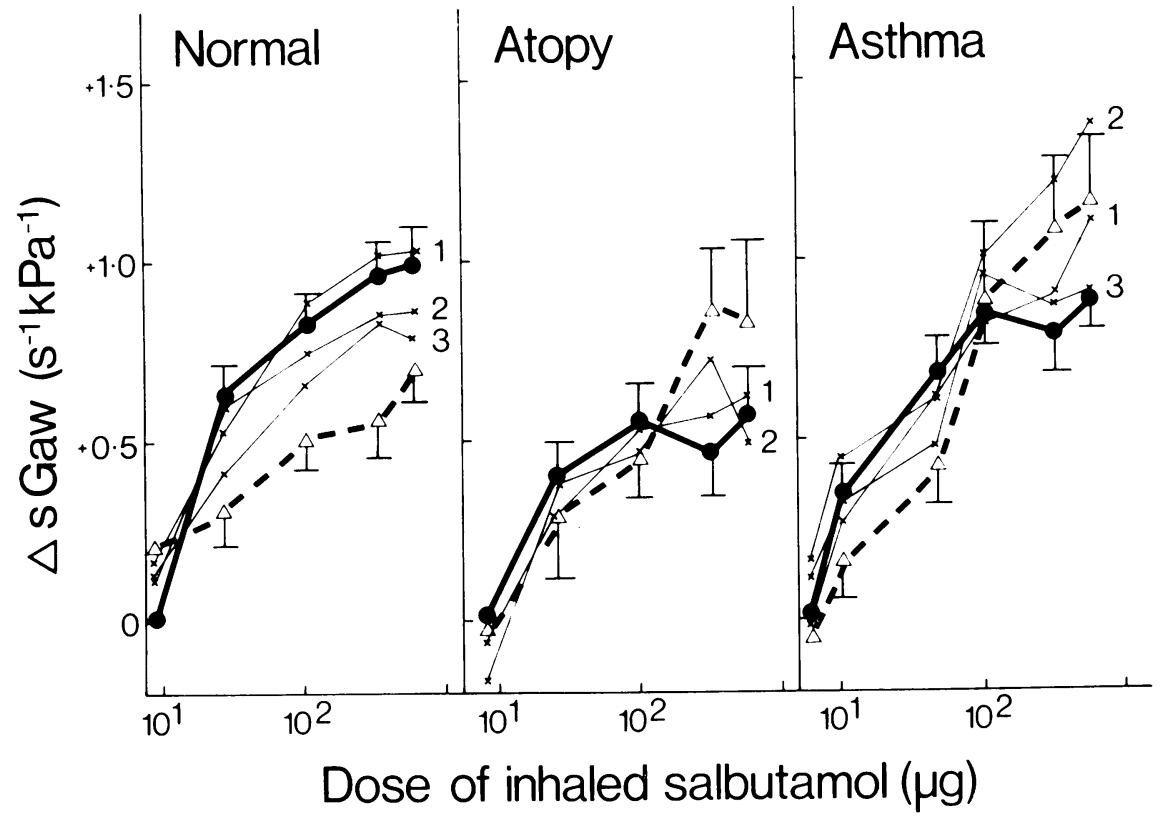

Fig 2 Mean change in sGaw from control baseline sGaw for each salbutamol dose-response study for the normal, atopic, and asthmatic subjects. The bold lines are control values

$\longrightarrow \longrightarrow$ and week $4 \triangle-\triangle$, with weeks 1, 2, and 3 in fainter lines $X-X$ (week 3 was omitted in the atopic group).

ATOPY


ASTHMA
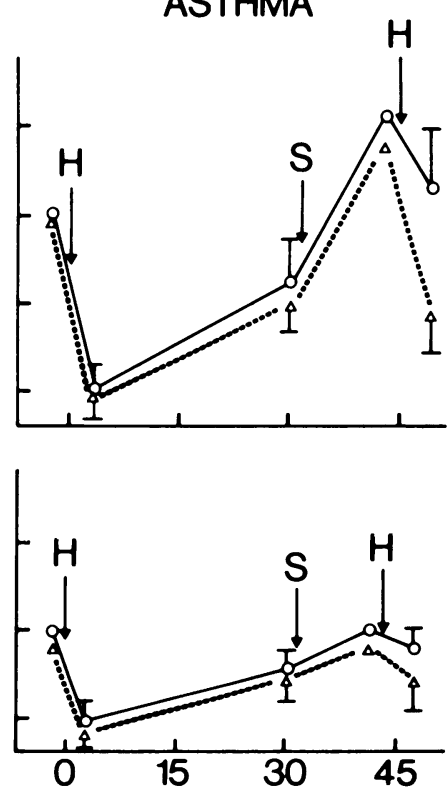

TIME (min)

$\mathrm{H}=$ histamine inhalation, $\mathrm{S}=100 \mu \mathrm{g}$ salbutamol inhalation

Fig 3 Histamine challenge studies. Mean change in $s G a w\left(s^{-1} k \mathrm{~Pa}^{-1}\right)$ and $F E V_{1}$ (litres) + 1 SEM for six atopic and eight asthmatic subjects, before $\bigcirc-\bigcirc$ and during week 4 $\triangle-\triangle$ of regular salbutamol inhalations. 


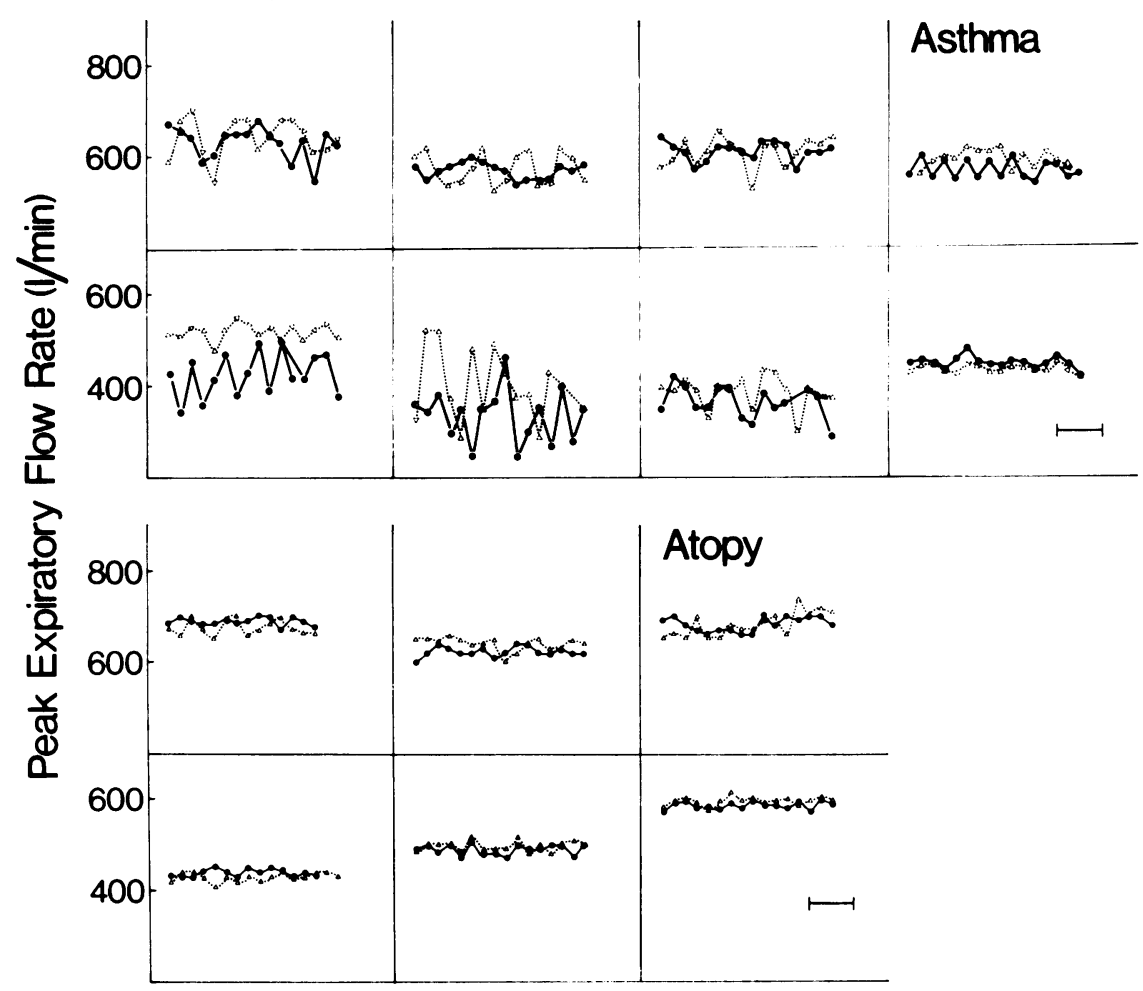

Fig 4 Individual peak flow values taken four times daily for four days for six atopic and eight asthmatic subjects before - and during week $4 \triangle-\triangle$ of regular salbutamol inhalations. $\mapsto=24$ hours.

\section{Results}

BASELINE VALUES FOR SGAW AND FEV 1 Mean baseline values for $\mathrm{SGaw}$ and $\mathrm{FEV}_{1}$ for the three groups of subjects are shown in table 2 . There was no significant difference in control values for sGaw and $\mathrm{FEV}_{1}$ between the normal and atopic subjects, but both groups had significantly higher baseline values than the asthmatic subjects $(p<0.05)$. The small differences in mean baseline sGaw between control period and week 4 were not significant for any of the three groups. The small fall in baseline $\mathrm{FEV}_{1}$ from control to week 4 was significant however for both the atopic $(4.45$ to 4.21 litres, $\mathrm{p}<0.05)$ and asthmatic group (3.68 to 3.33 litres, $\mathrm{p}<0.05$ ), but no change occurred in the normal subjects.

CONTROL SALBUTAMOL DOSE-RESPONSE STUDIES (TABLE 3, FIG 1)

There was a progressive increase in sGaw with increasing doses of salbutamol in all three groups; $60 \%$ in normal subjects ( $\mathrm{p}<0.001$ ), $30 \%$ in atopic subjects $(\mathrm{p}<0.005)$, and $65 \%$ in asthmatic subjects $(\mathrm{p}<0.003)$. The corresponding increases in $\mathrm{FEV}_{1}$ over baseline were $5 \%$ (normal), $3 \%$ (atopic), and $9 \%$ (asthmatic).

\section{SALBUTAMOL DOSE-RESPONSE STUDIES} DURING FOUR WEEKS' REGULAR

SALBUTAMOL (TABLE 3, FIG 2)

After regular inhalation of salbutamol, normal subjects showed a progressive decrease in the airway response to salbutamol, so that by week $4,600 \mu \mathrm{g}$ salbutamol produced only a $26 \%$ increase in sGaw compared with $60 \%$ in the control period ( $p<0.03$ ). This reduction was significant at all doses on the dose-response curve $(\mathrm{p}<0.03)$. The $\mathrm{FEV}_{1}$ response was $6 \%$ in week 4 compared with $5 \%$ in the control study.

In contrast, atopic subjects maintained their response to salbutamol; after four weeks' regular treatment an increase in sGaw of $41 \%$ after $600 \mu \mathrm{g}$ salbutamol was not significantly different from the $30 \%$ in the control study. There was a $6 \%$ increase in $\mathrm{FEV}_{1}$ in week 4 compared with $3 \%$ in the control 
study. Similarly, asthmatic subjects also maintained their response to salbutamol with a $93 \%$ increase in sGaw in week 4 compared with $65 \%$ in the control study after $600 \mu \mathrm{g}$ salbutamol $(\mathrm{p}>0.4)$. There was a $16 \%$ increase in $\mathrm{FEV}_{1}$ in week 4 compared with $9 \%$ in the control study $(\mathrm{p}=0.08)$.

\section{HISTAMINE CHALLENGE STUDIES}

Control baseline values of sGaw and $\mathrm{FEV}_{1}$ were lower in the asthmatic than the atopic subjects. Neither group showed any significant change in baseline sGaw or $\mathrm{FEV}_{1}$ between control period and week 4 (table 2), nor any difference in the sGaw or $\mathrm{FEV}_{1}$ response to histamine or in the protection afforded by salbutamol against histamine challenge (fig 3).

\section{PEAK EXPIRATORY FLOW RATES}

Mean values for PEFR in the control studies were $585 \pm 9.7$ and $494 \pm 9.81 / \mathrm{min}$ respectively for the atopic, non-asthmatic, and asthmatic groups (102 and $83 \%$ predicted). There was no significant change in the mean values during week $4(593 \pm 9.8$ and $519 \pm 9 \cdot 2 \mathrm{l} / \mathrm{min}$ ) nor any consistent change in individual peak expiratory flow patterns (fig 4).

\section{Discussion}

This is the first prospective study to compare airway responsiveness to a beta-agonist in normal and asthmatic subjects before and during treatment with large doses of inhaled salbutamol using the same technique. By choosing patients with mild and relatively stable asthma the problem of fluctuating airway calibre was reduced. The results suggest that normal subjects develop resistance after doses of inhaled salbutamol which do not cause resistance in asthmatic subjects. Baseline sGaw was lower in the asthmatic patients in the control study but the percentage increase in sGaw in response to salbutamol was similar in both groups (60 and $65 \%$ ). The atopic subjects had a smaller response to salbutamol $(30 \%)$, possibly because of their higher baseline sGaw, though this did not differ significantly from sGaw in the normal subjects.

After regular inhaled salbutamol the response of the normal and asthmatic subjects differed, with normal subjects developing a progressive fall in their airway response to salbutamol, while the asthmatic subjects clearly maintained their response. The extent and time-course of beta-adrenoceptor resistance in the normal subjects is very similar to that demonstrated in the only previous airway study of normal subjects. ${ }^{22}$ The atopic non-asthmatic subjects responded like the asthmatic patients, maintaining their airway responsiveness to salbutamol. The absence of any detectable resistance by week 4 in the salbutamol dose-response studies in these patients was further supported by the lack of any consistent change in the airway response to inhaled histamine or the protection afforded by salbutamol against a histamine challenge. Peak expiratory flow rates in both atopic and asthmatic subjects also showed no change in either mean values or diurnal pattern during the study. We have no way of ensuring that all subjects took regular salbutamol as prescribed, but all were considered reliable, all used a similar number of inhalers, and the findings were consistent within each group. The findings also fit with the clinical impression that patients with asthma rarely develop bronchial resistance to beta-agonists when inhaling amounts close to or above the recommended maximum dose. These results, therefore, suggest a true difference between normal subjects and asthmatic subjects, with atopic non-asthmatic subjects behaving like asthmatic subjects in this respect. The difference is probably a relative one since the studies of Van Metre ${ }^{5}$ and Reisman ${ }^{6}$ strongly suggest that bronchial beta-adrenoceptor resistance did develop in patients taking very large doses of beta-agonistsup to one inhaler a day.

The results in the asthmatic patients agree with most previous prospective studies in asthma in which comparable doses of beta-agonists have been used. These have usually been unable to demonstrate the development of bronchial beta-adrenoceptor resistance $;^{715-18}$ in contrast to studies on non-bronchial beta-adrenoceptor responses (tremor, heart rate, lymphocyte and leucocyte cyclic-AMP, and intermediary metabolites) where resistance has frequently developed. ${ }^{\text {10-14 }}$ Doses of beta-adrenoceptor agonists which result in impairment of tremor, lymphocyte cyclic-AMP, or metabolic responses in asthmatic patients may not impair airway responses, ${ }^{71224}$ even when given by inhalation. ${ }^{24}$ This suggests that tissues vary in the ease with which they develop resistance, with bronchial tissue being considerably less susceptible than other tissues in asthmatic patients.

The reduction in baseline $\mathrm{FEV}_{1}$ after four weeks' salbutamol treatment in the atopic and asthmatic subjects was unexpected and not associated with a significant reduction in sGaw. The changes may be transient since they were not found before histamine challenge in week 4 , nor was there any concurrent fall in PEFR or clinical deterioration. These results could be a chance finding, although a similar fall in PEFR and FEV 1 has been reported previously after regular adrenergic therapy. ${ }^{21} 25$ Since the changes affected $F_{E V}$ rather than sGaw they may reflect narrowing of small airways. A possible explanation would be increased bronchial mucus production 
since this has been demonstrated in animals and man after treatment with beta-adrenoceptor agonists. ${ }^{26} 27$ Alternatively, sudden withdrawal of large doses of beta-agonists may upset the autonomic control of mast cells, ${ }^{28}$ allowing a transient increase in mediator release.

The reason why normal and asthmatic subjects differ in their response to large doses of beta-agonists is not clear. Although asthmatic patients in this study showed no change in airway responsiveness to salbutamol after four weeks' regular salbutamol, the plasma cyclic-AMP response to intravenous salbutamol in the same subjects was reduced. ${ }^{24}$ If plasma cyclic-AMP levels reflect intracellular cyclicAMP levels in bronchial smooth muscle, failure to develop bronchial beta-adrenoceptor resistance suggests that there may be a protective mechanism independent of the beta-adrenoceptor. For example, increased intracellular steroid levels might induce a cyclic-AMP dependent protein kinase to augment the effect of intracellular cyclic-AMP. ${ }^{29}$ Alternatively, our findings may be the result of changes in the beta-adrenoceptor since plasma cyclic-AMP levels may not reflect concentrations of cyclic-AMP in bronchial smooth muscle, particularly in view of the differing susceptibilities of different tissues to develop resistance.

Recent beta-adrenoceptor radioligand binding studies have suggested that asthma may be associated with a reduced number of beta-adrenoceptors, ${ }^{30}$ or a relative increase in the alpha to beta-adrenoceptor ratio. ${ }^{31} 32$ Most of these changes are likely to be caused by previous treatment with beta-agonists since patients with asthma on no treatment have a normal number of leucocyte beta-adrenoceptor binding sites, ${ }^{33}$ and excess agonist, both in vitro ${ }^{34}$ and in vivo ${ }^{35}$ in normal subjects cause a reduction in leucocyte beta-adrenoceptor numbers. The number of beta-adrenoceptor radioligand binding sites does not necessarily reflect functional activity. An $85 \%$ reduction in leucocyte dihydroalprenolol binding sites was found in asthmatic subjects after moderate doses of oral terbutaline for only six days ${ }^{35}$ in marked contrast to the complete lack of any functional impairment in airway beta-adrenoceptor responsiveness in both our study and in previous studies of oral terbutaline. ${ }^{7}$ Also, the increased alpha/beta adrenoceptor ratio in sensitised guinea-pig lung was not associated with any change in the adenylate cyclase response to isoprenaline. ${ }^{32}$ The findings of leucocyte radioligand binding studies cannot be extrapolated to beta-adrenoceptor function in the airways, and do not help to determine the cause of the changes we observed.

We thank Dr ST Holgate for helpful advice and criticism, Mrs C Baldwin for technical assistance, and Mrs M Dowling for typing the paper. Allen and Hanbury's Ltd supplied the low dose salbutamol $\left(\right.$ Ventolin $\left.^{\mathrm{R}}\right)$ aerosols. The work in this paper is part of an MD thesis by JEH at London University.

\section{References}

${ }^{1}$ Inman WHW, Adelstein AM. Rise and fall of asthma mortality in England and Wales in relation to use of pressurised aerosols. Lancet 1969;2:279-85.

${ }^{2}$ Campbell AH. Mortality from asthma and bronchodilator aerosols. Med J Aust 1976;1:386-91.

${ }^{3}$ Heaf PJD. Deaths in asthma: a therapeutic misadventure? Br Med Bull 1970;26:245-7.

${ }^{4}$ Conolly ME, Davies DS, Dollery CT, George CF. Resistance to beta-adrenoceptor stimulants (a possible explanation for the rise in asthma deaths). $B r J$ Pharmacol $1971 ; 43: 389-402$.

${ }^{5}$ Van Metre TE. Adverse effects of inhalation of excessive amounts of nebulised isoproterenol in status asthmaticus. J Allergy 1969;43:101-13.

${ }^{6}$ Reisman RE. Asthma induced by adrenergic aerosols. $J$ Allergy 1970;46:162-77.

${ }^{7}$ Larsson S, Svedmyr N, Thiringer G. Lack of bronchial beta adrenoceptor resistance in asthmatics during long term treatment with terbutaline. J Allergy Clin Immunol 1977;59:93-100.

${ }^{8}$ Holgate ST, Stubbs WA, Wood PJ, McCaughey ES, Alberti KGMM, Tattersfield AE. Airway and metabolic resistance to intravenous salbutamol: a study in normal man. Clin Sci 1980;59:155-61.

${ }^{9}$ Nelson HS, Black JW, Branch LB et al. Subsensitivity to epinephrine following the administration of epinephrine and ephedrine to normal individuals. $J$ Allergy Clin Immunol 1975;55:299-309.

10 Jenne JW, Chick TW, Strickland RD, Wall FJ. Subsensitivity of beta responses during therapy with a longacting beta-2 preparation. J Allergy Clin Immunol 1977; 59:383-90.

1 Paterson JW, Conolly ME, Davies DS, Dollery CT. Isoprenaline resistance and the use of pressurised aerosols in asthma. Lancet 1968;2:426-9.

12 Morris HG, Rusnak SA, Selner JC, Barzens K, Barnes J. Comparative effects of ephedrine on adrenergic responsiveness in normal and asthmatic subjects. $J$ Allergy Clin Immunol 1978;61:294-302.

${ }^{13}$ Greenacre JK, Schofield P, Conolly ME. Desensitization of the $\beta$-adrenoceptor of lymphocytes from normal subjects and asthmatic patients in vitro. $\mathrm{Br} J$ Clin Pharmacol 1978;5:199-206.

${ }^{11}$ Parker CW, Smith JW. Alterations in cyclic adenosine monophosphate metabolism in human bronchial asthma. $J$ Clin Invest 1973;52:48-59.

${ }^{15}$ Gibson GJ, Tattersfield AE, Pride NB. The effects of oral salbutamol on response to inhaled isoprenaline in asthmatic subjects. Bull Physiopathol Respir 1972;8: 657-8.

${ }^{16}$ Formgren $\mathrm{H}$. The therapeutic value of oral long term treatment with terbutaline $\left(\right.$ Bricany ${ }^{\mathrm{R}}$ ) in asthma. A follow up study of its efficacy and side effects. Scand $J$ Respir Dis 1975;56:321-8.

17 Wilson AF, Novey HS, Cloninger P, Davis J, White D. Cardiopulmonary effects of long-term bronchodilator administration. J Allergy Clin Immunol 1976;58:204-12.

${ }^{18}$ Peel ET, Gibson GJ. Effects of long-term inhaled salbutamol therapy on the provocation of asthma by histamine. Am Rev Respir Dis 1980;121:973-8. 
19 Miller J, Wallace D, Grieco MH, Frenkel R, Larsen K. Double-blind trial of oral carbuterol in bronchial asthma. Ann Allergy 1977;39:12-17.

${ }^{20}$ Plummer AL. The development of drug tolerance to beta adrenergic agents. Chest 1978;73:949-57. Suppl.

${ }^{21}$ Gibson GJ, Greenacre JK, König P, Conolly ME, Pride NB. Use of exercise challenge to investigate possible tolerance to beta-adrenoceptor stimulation in asthma. Br J Dis Chest 1978;72:199-206.

${ }^{22}$ Holgate ST, Baldwin CJ, Tattersfield AE. $\beta$-adrenergic agonist resistance in normal human airways. Lancet 1977;2:375-7.

${ }^{23}$ Tattersfield AE, Keeping IM. Assessing change in airway calibre-measurement of airway resistance. $\mathrm{Br} \mathrm{J}$ Clin Pharmacol 1979;8:307-19.

${ }^{24}$ Harvey JE, Baldwin CJ, Wood PJ, Alberti KGMM, Tattersfield AE. Airway and metabolic responsiveness to intravenous saibutamol in asthma: effect of regular inhaled salbutamol. Clin Sci 1981 ;60:579-85.

${ }^{25}$ Van Arsdel PP, Schaffrin RM, Rosenblatt J, Sprenkle AC, Altman LC. Evaluation of oral fenoterol in chronic asthmatic patients. Chest 1978;73:997-8. Suppl.

${ }^{26}$ Gallagher JT, Kent PW, Passatore M, Phipps RJ, Richardson PS. The composition of tracheal mucus and the nervous control of its secretion in the cat. Proc $R$ Soc Lond(Biol) 1975 ;192:49-76.

27 Williams IP, Phipps RJ, Wright NL, Pack RJ, Richardson PS. Sympathomimetic agonists stimulate mucus secretion into human bronchi. Thorax 1981;36:231(abstr).

${ }^{28}$ Orange RP, Austen WG, Austen KF. Immunological release of histamine and slow-reacting substance of anaphylaxis from human lung. I. Modulation by agents influencing cellular levels of cyclic $3^{\prime} 5^{\prime}$-adenosine monophosphate. J Exp Med 1971;134:136s-48s.

${ }^{29}$ Fuller DJM, Byus CV, Russell DH. Specific regulation by steroid hormones of the amount of type 1 cyclic-AMP dependent protein kinase holoenzyme. Proc Natl Acad Sci USA 1978;75:223-7.

${ }^{30}$ Brooks SM, McGowan K, Bernstein IL, Altenau P, Peagler J. Relationship between numbers of betaadrenergic receptors in lymphocytes and disease severity in asthma. $J$ Allergy Clin Immunol 1979;63:401-6.

${ }^{31}$ Szentivanyi A. The radioligand binding approach in the study of lymphocytic adrenoceptors and the constitutional basis of atopy. J Allergy Clin Immunol 1980; 65:5-11.

${ }^{32}$ Barnes PJ, Dollery CT, MacDermot J. Increased pulmonary $\alpha$-adrenergic and reduced $\beta$-adrenergic receptors in experimental asthma. Nature 1980;285:569-71.

${ }^{33}$ Galant SP, Duriseti L, Underwood S, Allred S, Insel PA. Beta-adrenergic receptors of polymorphonuclear particulates in bronchial asthma. J Clin Invest 1980;65: 577-85.

${ }^{34}$ Mukherjee C, Caron MG, Lefkowitz RJ. Regulation of adenylate cyclase coupled beta-adrenergic receptors by beta-adrenergic catecholamines. Endocrinology 1976;99: 347-57.

${ }^{35}$ Galant SP, Duriseti L, Underwood S, Insel PA. Decreased beta-adrenergic receptors on polymorphonuclear leukocytes after adrenergic therapy. $N$ Engl J Med 1978; 299:933-6. 